736.22

NC has

\title{
A STORMWATER MANAGEMENT MODEL FOR THE WEST BRANCH BRANDYWINE CREEK, CHESTER COUNTY, PENNSYLVANIA
}

U.S. Geological Survey Water-Resources Investigations $81-73$

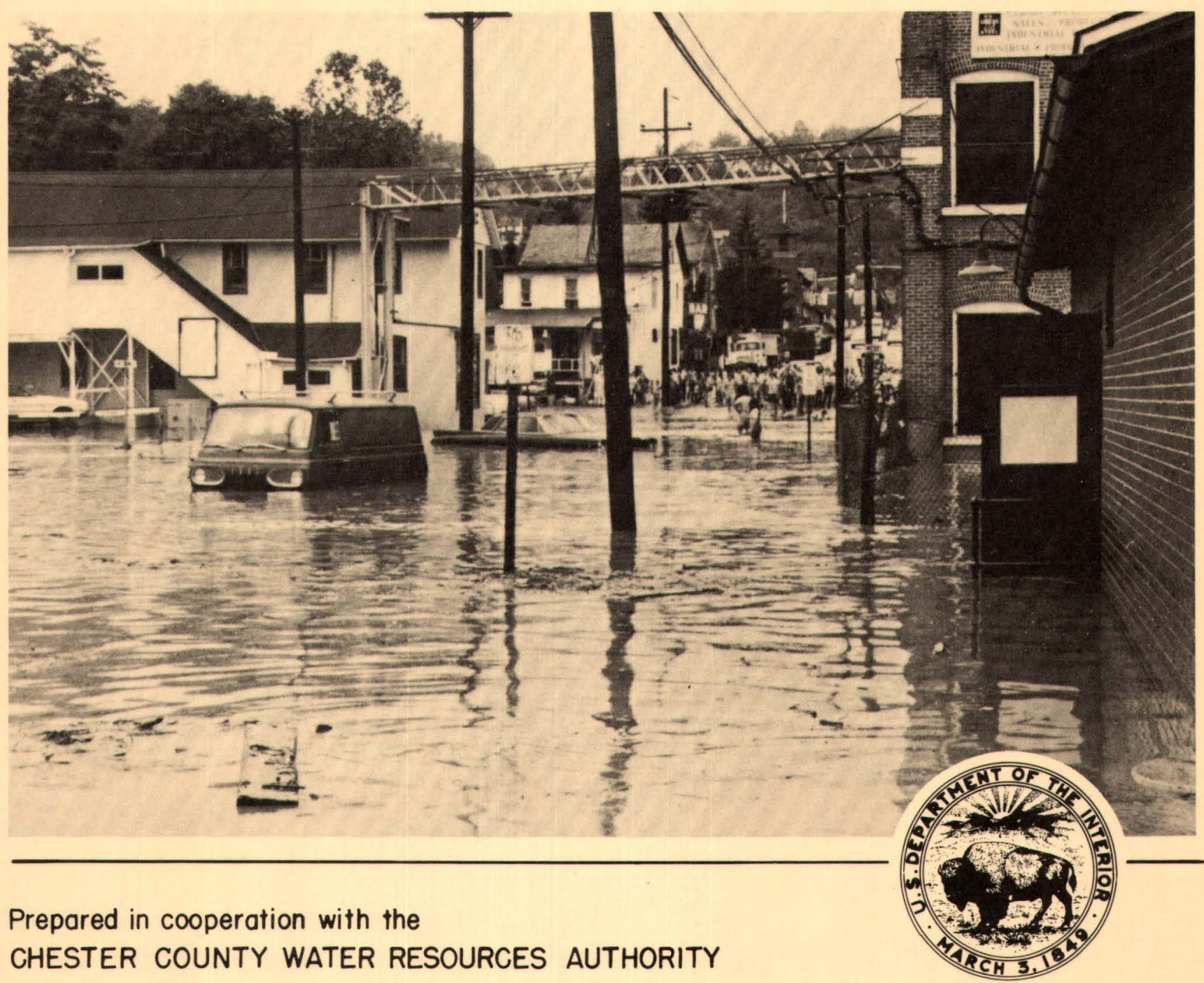




\begin{tabular}{|l|l|}
\hline REPORT DOCUMENTATION & 1.-REPORT NO. \\
PAGE &
\end{tabular}

4. Title and Subtitle
2.

3. Recipient's Accession No.

5. Report Date

February 1982

6.

8. Performing Organization Rept. No. USGS/WRI-81-73

10. Project/Task/Work Unit No.

11. Contract(C) or Grant(G) No.

(C)

(G)

13. Type of Report \& Period Covered

Fina1 1970-79

14.

P.O. Box 1107

Harrisburg, Pennsylvania 17108-1107

15. Supplementary Notes

Prepared in cooperation with the Chester County Water Resources Authority.

16. Abstract (Limit: 200 words)

Three subbasins in the West Branch Brandywine Creek were modeled by the Dawdy, Shaake, and Alley distributed routing rainfall-runoff model. The Honeybrook subbasin could not be calibrated because of nonrepresentative rainfall data; the Coatesville subbasin was calibrated, but not verified; and the Modena subbasin was calibrated and verified.

Predictive simulations were made using selected storms to determine the effects of projected population growth and four proposed flood-control structures in the Coatesville and Modena subbasins. Simulations of projected population growth in both subbasins showed that runoff volumes would have a greater percentage increase for low-magnitude floods than for high-magnitude floods. The effectiveness of any flood-control structure in the Coatesville subbasin depends upon the rainfall pattern in the West Branch Brandywine Creek basin and on whether or not it will be located upstream from a floodcontrol structure. In the Modena subbasin, the simulated effect of proposed floodcontrol structure PA-428 showed that it would lower the peak discharge of Sucker Run at State Route 82 and either raise or have no effect on peak discharge at West Branch Brandywine Creek at Modena.

17. Document Analysis a. Descriptors

*Rainfall-runoff model, *stormwater management, *flood control, urbanization, Pennsylvania

b. Identifiers/Open-Ended Terms

Chester County, Brandywine Creek

c. COSATI Field/Group

18. Availability Statement

No restrictions on distribution

19. Security Class (This Report) UNCLASSIFIED

20. Security Class (This Page) UNCLASSTFTED
21. No. of Pages 34 22. Price OPTIONAL FORM 272 (4-77) (Formerly NTIS-35) Department of Commerce 
A STORMWATER MANAGEMENT MODEL FOR THE WEST BRANCH

BRANDYWINE CREEK, CHESTER COUNTY, PENNSYLVANIA

By Rona1d A. Sloto

U.S. GEOLOGICAL SURVEY

Water-Resources Investigations 81-73

Prepared in cooperation with the

Chester County Water Resources Authority

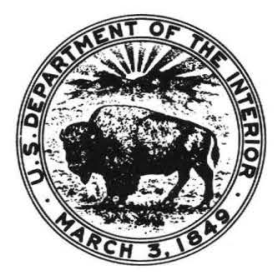


UNITED STATES DEPARTMENT OF THE INTERIOR

JAMES G. WATT, SECRETARY

GEOLOGICAL SURVEY

Dallas L. Peck, Director

For additional information write to:

U.S. Geological Survey

4th Floor Federal Building

P.0. Box 1107

Harrisburg, Pennsylvania 17108-1107

\section{Cover:}

Sucker Run at State Route 82, looking north, June 29, 1973.

Photograph courtesy of Lukens

Steel, Inc. 
Abstract -

Introduction - 1

Purpose and scope -_- 1

Description of project area

Acknowledgments _-_-_- 5

Description of rainfal1-runoff model

Soil-moisture accounting component 6

Rainfal1-excess component - 6

Optimization component - 6

Routing component -

Calibration and verification

Optimization of soil-moisture and infiltration parameters --_---- 10

Errors in input data

Honeybrook subbasin - 11

Coatesville subbasin - 11

Modena subbasin -_-_-_-_- 12

Predictive simulations - 17

Effects of projected population growth

Effects of proposed flood-control structures --

Coatesville subbasin -

Modena subbasin -

Summary - -

Selected references - 33

\section{ILLUSTRATIONS}

Figure 1.--Map showing location of project area - 3

2.--Map showing modeled subbasins and location of datacollection sites - 4

3.--Schematic diagram of model structure -

4.--Observed and simulated hydrographs for the June 29-30, 1973, storm in the Coatesville subbasin -- 18

5.--Observed and simulated hydrographs for the Ju1y 11-12, 1976, storm in the Coatesville subbasin -- 19

6.--Observed and simulated hydrographs for the June 21-23, 1972, storm in the Modena subbasin ------ 20

7.--Observed and simulated hydrographs for the August 26-28, 1971, storm in the Modena subbasin ------ 21

8.--Map showing location of proposed flood-control structures 
Table 1.--Description of soil-moisture and infiltration parameters used in the model

2.--Soil-moisture and infiltration parameter values for the Coatesville subbasin mode1 - 12

3.--Comparison of observed and simulated runoff volumes and peak discharges for the Coatesville subbasin model calibration -

4.--Soil-moisture and infiltration parameter values for the Modena subbasin mode1 - 14

5.-Comparison of observed and simulated runoff volumes and peak discharges for the Modena subbasin model calibration - - 15

6.--Comparison of observed and simulated runoff volumes and peak discharges for the Modena subbasin mode1 verification

7.--Projected population increases for municipalities in modeled subbasins

8.--Results of simulations with projected population for selected storms in the Coatesville and Modena subbasins

9.--Summary of proposed flood-control structure data -------- 26

10.--Results of simulations of selected storms with proposed flood-control structures in the Coatesville subbasin -- 27

11.--Results of simulations of a hypothetical 1 percent chance flood with proposed flood-control structures in the Coatesville subbasin

12.--Results of simulations of selected storms with proposed flood-control structure PA-428 in the Modena subbasin - 30

13.--Results of simulations with projected population for selected storms in the Modena subbasin with flood-control structures located in the Coatesville subbasin 
Length

inch (in)

foot (ft)

mile (mi)

square mile $\left(\mathrm{mi}^{2}\right)$

acre-foot (acre-ft)

cubic foot per second $\left(\mathrm{ft}^{3} / \mathrm{s}\right)$
25.4

0.3048

1.6093

Area

2.59

Volume

1233.0

0.001233

Flow

28.32

0.02832

\author{
millimeter (mm) \\ meter ( $\mathrm{m}$ ) \\ kilometer $(\mathrm{km})$
}

square kilometer $\left(\mathrm{km}^{2}\right)$

cubic meter $\left(\mathrm{m}^{3}\right)$

cubic hectorneter $\left(\mathrm{hm}^{3}\right)$

liter per second (L/s) cubic meter per second $\left(\mathrm{m}^{3} / \mathrm{s}\right)$ 

A STORMWATER MANAGEMENT MODEL FOR THE

WEST BRANCH BRANDYWINE CREEK, CHESTER COUNTY, PENNSYLVANIA

By Ronald A. S1oto

ABSTRACT

Three subbasins in the West Branch Brandywine Creek watershed were modeled by the Dawdy, Schaake, and Alley distributed routing rainfallrunoff model. The Honeybrook subbasin could not be calibrated because of nonrepresentative rainfall data. The Coatesville subbasin was calibrated, but not verified; the average standard error of estimate is 34 percent for peak discharge. The Modena subbasin was calibrated and verified. Average error for peak discharge is 38 percent for calibration and 24 percent for verification.

Predictive simulations using selected storms were made to determine the effects of projected population and four proposed flood-control structures in the Coatesville and Modena subbasins. Simulations of projected population growth in both subbasins showed that runoff volumes would generally have a greater percentage increase for low-magnitude floods than for highmagnitude floods. Proposed flood-control structure PA-436D had the greatest reduction in peak discharge at West Branch Brandywine Creek at Coatesville when a large quantity of runoff entered the Coatesville subbasin from upstream. WA-2 had the greatest reduction in peak discharge when most of the runoff came from within the Coatesville subbasin. A1though WA-2 and PA-430 will control about the same drainage area, WA-2 causes a greater reduction in peak discharge at Coatesville because PA-430 is to be located upstream from Rock Run Reservoir, which provides some floodwater storage. In the Modena subbasin, the simulated effect of proposed flood-control structure PA-428 showed that it would lower the peak discharge of Sucker Run at State Route 82 and either raise or have no effect on peak discharges at West Branch Brandywine Creek at Modena. Most simulations of the effects of proposed flood-control structures in the Coatesville subbasin on peak discharge at Modena showed a reduction in peak discharge.

\section{INTRODUCTION}

\section{Purpose and Scope}

From 1970 to 1980, population in the Brandywine Creek basin increased 19 percent. This growth, caused partly by increased employment in business and industry in Chester County, is changing the basin from rural to suburban, with a consequent increase in stormwater runoff. Periodic floods cause millions of dollars in damage--the Ju1y 21, 1979, flood caused over $\$ 6$ million damage in the Sucker Run subbasin.

This investigation, done in cooperation with the Chester County Water Resources Authority, has two purposes: (1) to determine the feasibility of rainfall-runoff modeling in the Brandywine Creek basin based on available data; and (2) to provide a calibrated model for stormwater management by Chester County. The results of the study will enable the County to meet some of the provisions of Pennsylvania Storm Water Act 167. 
This report describes rainfa11-runoff modeling for three subbasins of the West Branch Brandywine Creek basin. Effects of increased runoff from continued urbanization of the basin and of proposed flood-control structures for both the present and projected population are evaluated for the West Branch Brandywine Creek at Coatesville and Modena and for Sucker Run at State Route 82 .

\section{Description of Project Area}

The West Branch Brandywine Creek drains part of western Chester County and a small part of Lancaster County in southeastern Pennsylvania (fig. 1 ). It is a major tributary of Brandywine Creek, which flows into the Delaware River. The project area is the three subbasins $\left(55.0 \mathrm{mi}^{2}\right)$, shown in figure 2, upstream from the stream-gaging station at Modena (01480617).

Streamflow from the upper subbasin $\left(18.7 \mathrm{mi}^{2}\right)$ is measured at West Branch Brandywine Creek near Honeybrook (01480300). The major tributaries to the West Branch Brandywine Creek in the Honeybrook subbasin are Two Log Run and an unnamed tributary. The slope of the West Branch Brandywine Creek in this subbasin is 28.2 feet per mile. Average discharge for 20 years of record $(1960-80)$ is $26.3 \mathrm{ft}^{3} / \mathrm{s}$. The maximum discharge, $8,140 \mathrm{ft}^{3} / \mathrm{s}$, occurred on June 22,1972 .

Station West Branch Brandywine Creek at Coatesville (01480500) measures streamflow from the upper and middle subbasins $\left(45.8 \mathrm{mi}^{2}\right)$. The Coatesville subbasin, lying between the Honeybrook and Coatesville stream-gaging stations, has a drainage area of $27.1 \mathrm{mi}^{2}$. The major tributaries are Birch Run and Rock Run. The slope of the West Branch Brandywine Creek in this subbasin is 22.9 feet per mile. The average discharge at the Coatesville station for 18 years of record $(1943-51,1970-80)$ is $75.3 \mathrm{ft}^{3} / \mathrm{s}$. The maximum discharge, 8,100 $\mathrm{ft}^{3} / \mathrm{s}$, occurred on June 29, 1973.

Station West Branch Brandywine Creek at Modena (01480617) measures streamflow from all three subbasins $\left(55.0 \mathrm{mi}^{2}\right)$. The Modena subbasin, lying between the Coatesville and Modena stream gages, has a drainage area of $9.2 \mathrm{mi}^{2}$. The main tributary is Sucker Run, which drains $4.8 \mathrm{mi}^{2}$. Average discharge at the Modena station for 10 years of record (1970-80) is $105 \mathrm{ft}^{3} / \mathrm{s}$. The maximum discharge, 9,600 $\mathrm{ft}^{3} / \mathrm{s}$, occurred on June 29, 1973.

The Honeybrook subbasin is rural with most of the land being agricultural or woodland. The borough of Honeybrook (1980 population 1, 152) is near the center of the subbasin. The Coatesville subbasin is mostly rural, but is changing from rural to suburban. The Modena subbasin is highly urbanized and industrialized in parts. Heavy industry is located along the banks of the West Branch Brandywine Creek and Sucker Run. The Modena subbasin includes the city of Coatesville (1980 population 10,687), the borough of South Coatesville (1980 population 1,354), and part of the borough of Modena (1980 population 675).

The topography of the watershed is gent1y rolling hills, which are underlain by deeply weathered crystalline rock. Altitude ranges from $1,060 \mathrm{ft}$ at Welsh Mountain on the northern drainage divide to $265 \mathrm{ft}$ at the Modena stream-gaging station. 


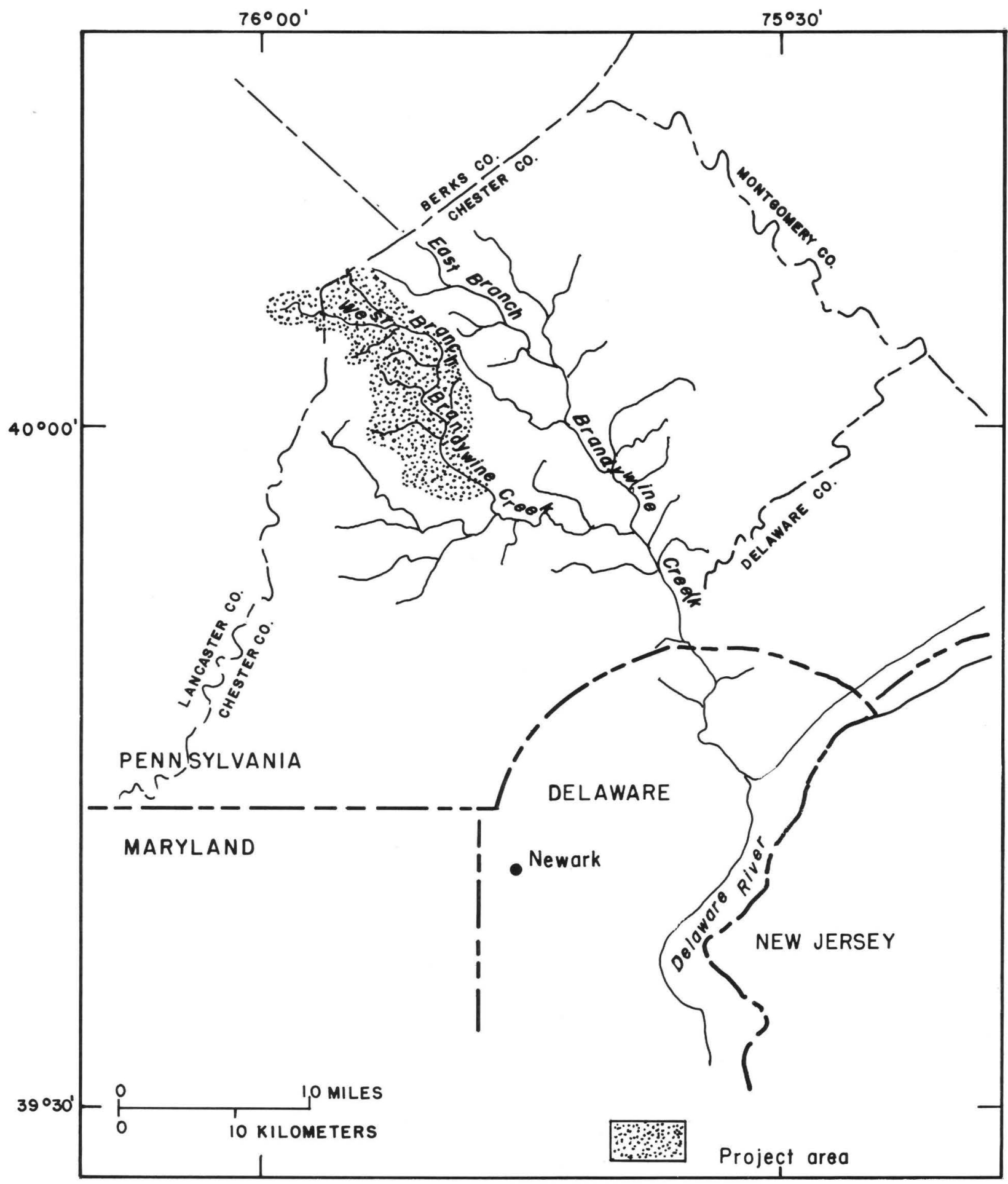

Figure 1.--Location of project area. 


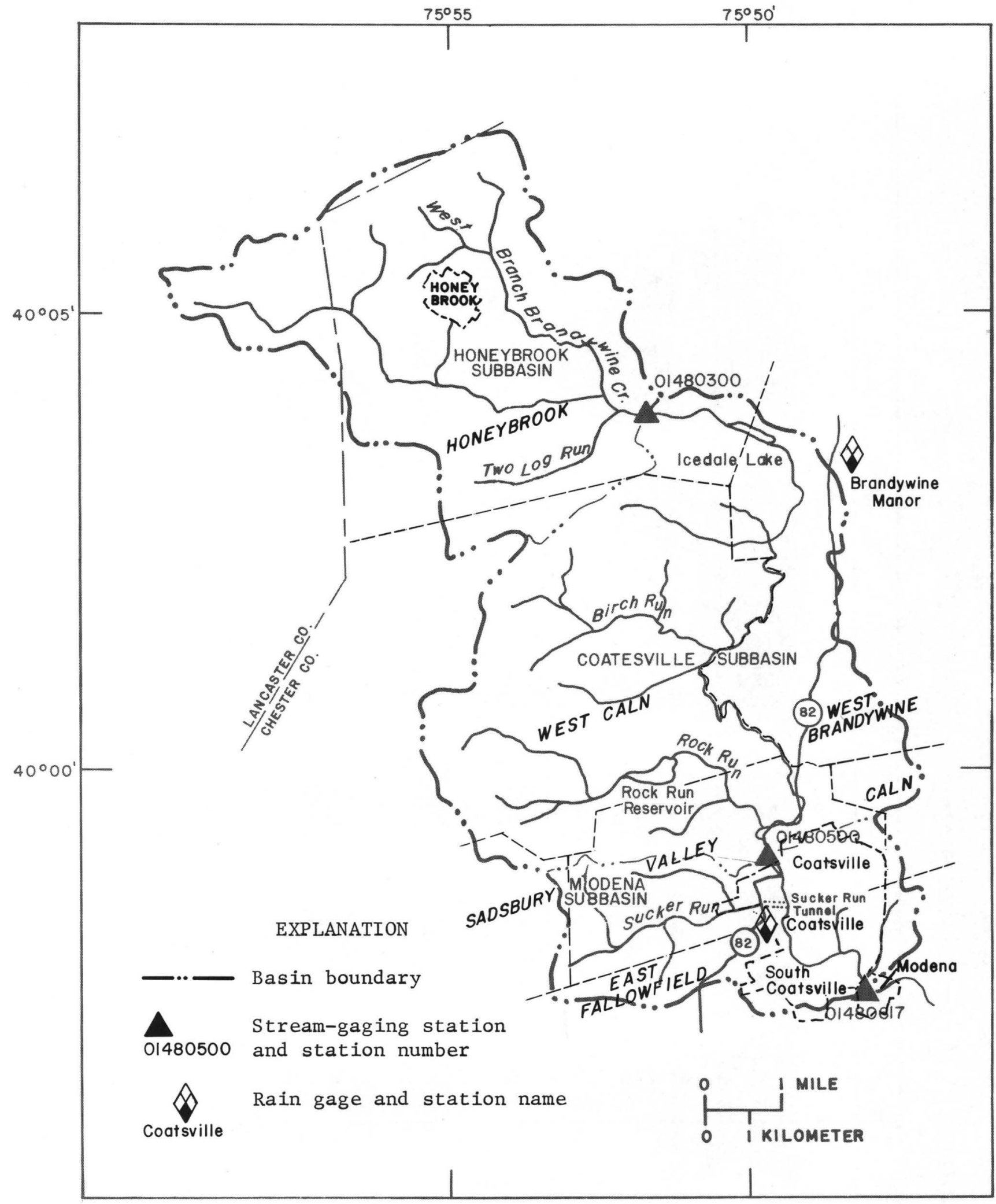

Figure 2.--Modeled subbasins and data-collection sites. 
The area has a modified humid continental climate. Average monthly temperature ranges from $0^{\circ} \mathrm{C}$ in January to $24^{\circ} \mathrm{C}$ in July. The average annual precipitation is approximately 45 inches and is generally evenly distributed throughout the year. Prevailing westerly winds carry most of the weather disturbances that affect the area, except for coastal storms, from the interior of the United States (Chester County Planning Commission, 1963). Much of the summer precipitation comes from thunderstorms that produce brief periods of high intensity rainfall. During the storm of July 21,1979 , the Coatesville rain gage recorded 7.35 inches of rain in 3 hours. The maximum rainfall intensity was 3.60 inches in 1 hour.

\section{Acknowledgments}

The cooperation of county and local officials who provided essential information is gratefully acknowledged. The author is particularly indebted to the Soil Conservation Service for providing storage-outflow data on proposed flood-control structures and to the Brandywine Valley Association for data from its Brandywine Manor rain gage.

\section{DESCRIPTION OF THE RAINFALL-RUNOFF MODEL}

Three subbasins in the West Branch Brandywine Creek basin were modeled with the distributed routing rainfall-runoff model developed by Dawdy, Schaake, and Alley (1978). It is a digital model that uses a deterministic mathematical approach based on approximation of physical laws. Input data for the model includes daily and unit rainfall, daily pan evaporation, unit streamflow, and inflow from upstream subbasins. Model parameters are soil moisture, infiltration, and routing. The model optimizes soil-moisture and infiltration parameters to produce the best fit between observed and simulated runoff volumes. During a modeled storm, the optimized set of soilmoisture and infiltration parameters are used to compute rainfall excess, based on antecedent soil-moisture conditions. Rainfall excess is used by the routing component to compute discharge. A more detailed description of the model is given in the following sections.

The routing, soil-moisture, and infiltration parameters can be adjusted to best simulate observed runoff volumes and peak discharges. There are many interactions among parameters, especially among the soil-moisture and infiltration parameters. Adjustment of one parameter can often be compensated for by adjustment of another parameter, so that many sets of parameters may fit a given set of data equally well. The initial parameter values represent the best estimate of the physical values in the basin; the set of optimized parameter values may not correspond to the actual parameter values. 
The soil-moisture-accounting component measures the effect of antececent conditions on infiltration. It simulates moisture redistribution in the soil column and evapotranspiration from the soil. Soil moisture is modeled as a two-layered system. During periods between modeled storms, a part of the daily rainfall, determined by the coefficient RR, infiltrates into soil-moisture storage (SMS), the upper soil-moisture zone. Evapotranspiration takes place from SMS, or from the lower soil-moisture zone, base-moisture storage (BMS), when $S M S=0$. The evapotranspiration rate is determined by multiplying the daily pan evaporation by a pan coefficient, EVC. Moisture from SMS drains into BMS at a rate determined by the drainage coefficient DRN. Storage in BMS has a maximum value, BMSN, which is equivalent to field capacity. When BMSN is exceeded, the excess moisture is assumed to enter the ground-water system.

\section{Rainfal1-Excess Component}

The rainfall-excess component is computed by a variation of the Green and Ampt (1911) equation. During a modeled storm, moisture is added to SMS based on:

$$
\mathrm{FR}=\mathrm{KSAT}(1+\mathrm{PS} / \mathrm{SMS}) \text {, }
$$

where

$$
\begin{aligned}
\mathrm{FR} & =\text { point-potential infiltration } \\
\mathrm{KSAT} & =\text { the effective saturated-soil hydraulic } \\
& \text { conductivity, and } \\
\mathrm{PS} & =\text { capillary potential at the wetted front. }
\end{aligned}
$$

PS is varied over the range from wilting point to field capacity by:

$$
\mathrm{PS}=\mathrm{PSP}[(\mathrm{RGF}-(\mathrm{RGF}-1) \mathrm{BMS} / \mathrm{BMSN}],
$$

where

$$
\begin{aligned}
\text { PSP }= & \text { suction at the wetting front at field } \\
& \text { capacity, and } \\
\text { RGF }= & \text { ratio of suction at wilting point to } \\
& \text { that at field capacity. }
\end{aligned}
$$

Soil-moisture and infiltration parameters used in the model are listed in table 1 .

\section{Optimization Component}

The model includes a component to calibrate the soil-moisture and infiltration parameters. Determination of optimum parameter values is based on the Rosenbrock (1960) optimization technique. This technique adjusts the parameter values to produce the closest match between the observed and simulated runoff volumes for selected storms. 
Table 1.--Description of the soil-moisture and infiltration parameters used in the model

\begin{tabular}{|c|c|c|}
\hline Parameter & Units & Description \\
\hline $\mathrm{RR}$ & - & $\begin{array}{l}\text { Proportion of daily rainfal1 } \\
\text { that infiltrates into the soil }\end{array}$ \\
\hline EVC & - & $\begin{array}{l}\text { Coefficient that converts pan } \\
\text { evaporation to potential evaporation }\end{array}$ \\
\hline DRN & $\begin{array}{l}\text { inches } \\
\text { per hour }\end{array}$ & $\begin{array}{l}\text { Constant drainage rate that controls } \\
\text { drainage of infiltrated soil moisture } \\
\text { from SMS to BMS }\end{array}$ \\
\hline BMSN & inches & $\begin{array}{l}\text { Maximum effective soil-moisture- } \\
\text { storage volume at field capacity }\end{array}$ \\
\hline KSAT & $\begin{array}{l}\text { inches } \\
\text { per hour }\end{array}$ & $\begin{array}{l}\text { Effective saturated hydraulic } \\
\text { conductivity }\end{array}$ \\
\hline PSP & $\begin{array}{l}\text { inches of } \\
\text { pressure }\end{array}$ & $\begin{array}{l}\text { Suction at the wetting front for soil } \\
\text { moisture at field capacity }\end{array}$ \\
\hline RGF & - & $\begin{array}{l}\text { Ratio of suction at the wetting front } \\
\text { for soil moisture at the wilting point } \\
\text { to that at field capacity }\end{array}$ \\
\hline
\end{tabular}

\section{Routing Component}

Each subbasin is represented by overland flow, channe1, noda1, and reservoir segments, which are described by a set of parameters. Overland flow segments receive uniformly distributed lateral inflow from excess rainfa11. Channel segments receive lateral inflow from overland flow segments and upstream inflow from other segments. Two types of nodal segments are used: (1) a junction segment used when more than three segments contribute inflow to the upstream end of a channel segment; (2) an input-hydrograph point used to input the discharge from an upstream subbasin. Reservoir segments are detention reservoirs which use modified-Puls routing (Soil Conservation Service, 1972). A user-specified table of storage versus outflow is used by the model for reservoir routing.

Input data needed to define routing parameters were measured in the field or taken from aerial photographs, topographic quadrangle maps, and $1: 2,400$ scale topographic maps provided by the Chester County Water Resources Authority. Routing parameters include segment length, slope, roughness, and one or two other special parameters given below. 
Channel segment length and slope were taken from topographic maps. The roughness parameter, similar to Manning's n, was estimated in the field. Special parameters of width and height for rectangular channels and bridge openings, width of cross section at a 1-foot depth for triangular channels, and diameter of culverts were measured in the field. Channel segment parameters to describe the Coatesville storm-sewer system were taken from data provided by the city of Coatesville.

Overland flow segment length is computed by dividing the area that contributes runoff by the length of stream that drains the contributing area. The contributing areas were planimetered. Stream lengths and overland flow segment slopes were taken from topographic maps. The roughness parameter, an empirical coefficient for overland flow, was estimated from topography. Percentage of impervious, pervious, and effective impervious areas (impervious areas directly connected to the channel drainage system) were calculated from field measurements, aerial photographs, and topographic maps.

The storage-outflow relationships for Icedale Lake and Rock Run Reservoir were computed from field measurements and data provided by the Chester County Water Resources Authority and the city of Coatesville. The storage-outflow relationships for proposed flood-control structures were provided by the Soil Conservation Service.

Excess rainfall is routed for both overland flow and channel segments by applying kinematic wave theory. Because kinematic wave equations are difficult to solve analytically, a numerical solution is used. A finite difference equation, which converges to the differential equation as the step size decreases, is solved. The kinematic wave equation to be solved for each channel and overland flow segment is:

where

$$
\frac{\partial A}{\partial t}+\frac{\partial Q}{\partial x}=q
$$

$$
\begin{aligned}
A= & \text { area of flow, } \\
Q= & \text { rate of flow, } \\
q= & \text { rate of lateral inflow, } \\
t= & \text { time, and } \\
x= & \text { distance along a segment increasing in } \\
& \text { the downstream direction. }
\end{aligned}
$$

A detailed description of the finite-difference scheme used to solve this equation is given in Dawdy, Schaake, and Alley (1978).

Model components are shown in figure 3, which is a schematic diagram of the model structure. 
Soil-moisture

accounting

component

Input

Daily rainfal1

6 Daily pan evaporation

\begin{tabular}{l}
\hline Parameters \\
RR, EVC, DRN \\
BMSN \\
Variables \\
BMS, SMS
\end{tabular}

Infiltration component

Output

BMS, SMS

Input

$\longrightarrow$

Unit rainfall

BMS, SMS

Parameters
KSAT, PSP, $\rightarrow \frac{\text { Output-Input }}{\text { Rainfal1 excess }}$

RGF, BMSN

Variables

BMS, SMS, FR
Routing component

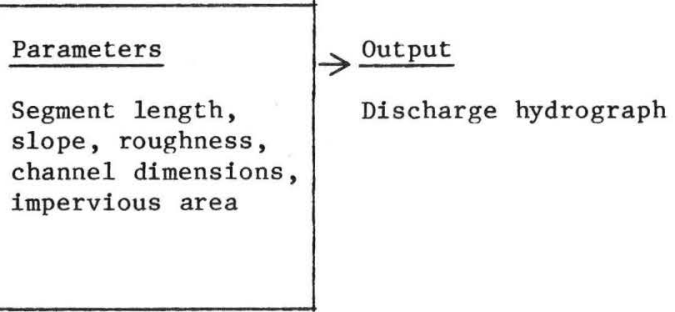

Figure 3.--Schematic diagram of mode1 structure. 
Al1 storms from 1970 to 1978 that produced a peak discharge above a selected base were screened for modeling. The selected base discharges are $300 \mathrm{ft}^{3} / \mathrm{s}$ at the Honeybrook gage, $500 \mathrm{ft}^{3} / \mathrm{s}$ at the Coatesville gage, and $750 \mathrm{ft}^{3} / \mathrm{s}$ at the Modena gage. Unit discharge at a 15-minute recording interval was obtained by processing digital tapes from the gaging stations for all storms that produced peak discharges above base. Daily and hourly rainfall data for the Coatesville and Brandywine Manor rain gages were obtained from the National Oceanic and Atmospheric Administration (NOAA) and the Brandywine Valley Association, respectively. Hourly rainfall data were converted to 15-minute data for compatiblity with unit streamflow. Daily pan evaporation was obtained from NOAA for the Newark, Delaware station, which is 22 miles south of Coatesville. During screening, storms were deleted if they lacked rainfall or discharge data. Discharge data for both the upstream and downstream gages were necessary in the Coatesville and Modena subbasins. The remaining storms were ranked and divided into comparable calibration and verification sets for each subbasin.

\section{Optimization of Soil-Moisture and Infiltration Parameters}

Using the storms selected for calibration, the soil-moisture and infiltration parameters for each subbasin were optimized. The upper and lower limits for PSP, RGF, and BMSN are from Alley and Smith (written communication, 1980). The range for KSAT, based on the general soil map of Chester County (Kunkle, 1963) and the Soil Conservation Service (1972) hydrologic soil group designation, should be 0.4-0.8 for the Honeybrook and Coatesville subbasins and 0.3-0.8 for the Modena subbasin (Alley and Smith, written communication, 1980). Values of KSAT in this range produced large errors in computed runoff volumes. Values in the range 0.05-0.2 produced much better matches between the observed and simulated runoff volumes.

EVC, DRN, and RR were not optimized. EVC was set at 0.75 and DRN at 1.0 based on rainfal1-runoff modeling in Southeastern Pennsylvania (Ross, personal communication, 1980). RR was varied from 0.7 to 0.9 and then set at the value that produced the best match between the observed and simulated runoff volumes.

Initial parameter values were set at the mean of the limiting values and optimized to produce a set of simulated runoff volumes. The simulated runoff volumes were compared with the observed runoff volumes. The parameter values were then adjusted on the basis of this comparison. This set of adjusted parameter values was used as the initial values and optimized to produce a new set of simulated runoff volumes. This was done a few times until the best fit between simulated and observed runoff volumes was obtained.

\section{Errors in Input Data}

Modeling was done using available data, which contain errors of unknown magnitude. Errors in the rainfall and streamflow data are reflected both in the soil-moisture and infiltration parameter optimization and in the model output hydrograph. 
Rainfall data used as input to the model are subject to sampling errors and errors introduced in data reduction. A rain gage measures only the amount of precipitation at the gage, and this amount is assumed to be representative of the entire subbasin. However, the quantity, intensity, and duration measured at the rain gage is not necessarily the same over the entire subbasin. Data from only two rain gages were available. The Coatesville rain gage is in the Modena subbasin. The Brandywine Manor rain gage is just outside of the Coatesville subbasin (fig. 2). The Honeybrook and Coatesville subbasins have no rain gages. When hourly rainfall data were reduced to 15-minute data, rainfall was assumed to be distributed evenly throughout the hour; this may not have been true.

Model accuracy for runoff volumes, peak discharges, and hydrograph match depends upon the accuracy of the rating curves for the stream gages. The uppermost part of the rating curves for the three stream gages are defined by indirect discharge measurements after the flood of June 22 , 1972, and a few current meter measurements. Accuracies of the indirect measurements range from an "estimate" at Honeybrook, to poor at Coatesville, and good at Modena.

\section{Honeybrook Subbasin}

The Honeybrook subbasin is described by 26 overland flow and 13 channe 1 segments. Nineteen storms from 1970 to 1976 that had peak discharges ranging from 300 to $8,130 \mathrm{ft}^{3} / \mathrm{s}$ were selected for calibration. Unit data from the Coatesville and Brandywine Manor rain gages were used separately and together, both with equal and unequal weighting. A satisfactory calibration was not achieved. Unsuccessful calibration is most likely caused by sampling error. The Coatesville rain gage is 9 miles south of the center of the subbasin and the Brandywine Manor rain gage is 5 miles southeast of the center of the subbasin. Rainfall measured by these gages is, apparently, not representative of the actual rainfall distribution over the Honeybrook subbasin.

\section{Coatesville Subbasin}

The Coatesville subbasin is described by 38 overland flow segments, 18 channel segments, two reservoir segments, and one input-hydrograph point. The two reservoir segments correspond to Icedale Lake and Rock Run Reservoir. The input-hydrograph point is used to input streamflow from the Honeybrook subbasin.

Seventeen storms from 1970 to 1977 that had peak discharges ranging from 578 to $7,550 \mathrm{ft}^{3} / \mathrm{s}$ were selected for calibration, and 17 storms from 1970 to 1976 that had discharges ranging from 572 to $7,910 \mathrm{ft}^{3} / \mathrm{s}$ were selected for verification. Simulations were made with unit data from the Coatesville and Brandywine Manor rain gages separately and together, both with equal and unequal weighting. A simulation was also made with unit data from each rain gage weighted proportional to the distance of each overland flow segment from the rain gages. The simulation with the rainfall for Coatesville gave the best results, both for runoff volume and peak discharge. In some of the storm simulations where unit data were not available from the Coatesville rain gage, unit data from the Brandywine Manor rain gage were substituted with good results. 
Model calibration produced an average standard error of estimate of 61 percent for peak discharge; model verification produced an average error of 63 percent for peak discharge. These errors were not acceptable; therefore, the calibration and verification storms were combined and 25 storms were selected to calibrate the model. These storms from 1970 to 1977 had peak discharges ranging from 572 to $7,910 \mathrm{ft}^{3} / \mathrm{s}$. Model calibration using these storms produced an error of 34 percent for peak discharge and 54 percent for runoff volumes. No verification was performed. Soil-moisture and infiltration parameter values for the Coatesville subbasin model are given in table 2. A comparison of the observed and simulated runoff volumes and peak discharges for the Coatesville subbasin model calibration are given in table 3 .

Table 2.--Soil-moisture and infiltration parameter values
for the Coatesville subbasin model

\begin{tabular}{cc}
\hline Parameter & Value used in model \\
\cline { 2 - 2 } PSP & 1.03 \\
KSAT & 0.10 \\
RGF & 18.70 \\
BMSN & 2.01 \\
EVC & 0.75 \\
RR & 0.85 \\
DRN & 1.0 \\
\hline
\end{tabular}

\section{Modena Subbasin}

The Modena subbasin is described by 36 overland flow segments, 21 channel segments, 4 junction segments, and an input-hydrograph point used to input streamflow from the upstream subbasins. Rainfall data are from the Coatesville rain gage which is near the center of the subbasin. Fourteen storms from 1970 to 1979 that had peak discharges ranging from 834 to $7,940 \mathrm{ft}^{3} / \mathrm{s}$ were used for calibration. Soil-moisture and infiltration parameter values for the Modena subbasin model are given in table 4. The average standard error of estimate was 38 percent for peak discharge and 60 percent for runoff volume. The comparison of observed and simulated runoff volumes and peak discharges for the Modena subbasin model calibration are given in table 5 .

Fourteen storms from 1970 to 1978 that had peak discharges ranging from 774 to $3,390 \mathrm{ft}^{3} / \mathrm{s}$ were used for model verification. The average standard error of estimate was 24 percent for peak discharge and 98 percent for runoff volume. A comparison of observed and simulated runoff volumes and peak discharges for the Modena subbasin model verification are given in table 6 . 
Table 3.--Comparison of observed and simulated runoff volumes and peak discharges for the Coatesville subbasin model calibration

\begin{tabular}{|c|c|c|c|c|c|c|}
\hline \multirow[b]{2}{*}{$\begin{array}{l}\text { Storm } \\
\text { Number }\end{array}$} & \multirow[b]{2}{*}{ Storm Date } & \multirow[b]{2}{*}{$\begin{array}{c}\text { Storm rainfall } \\
\text { (inches) }\end{array}$} & \multicolumn{2}{|c|}{ Observed } & \multicolumn{2}{|c|}{ Simulated } \\
\hline & & & $\begin{array}{l}\text { Runoff volume } \\
\text { (inches) }\end{array}$ & $\begin{array}{l}\text { Peak discharge } 2 / 1 \\
\left(\mathrm{ft}^{3} / \mathrm{s}\right)\end{array}$ & $\begin{array}{l}\text { Runoff volume } \\
\text { (inches) }\end{array}$ & $\begin{array}{l}\text { Peak discharge } 2 \\
\left(\mathrm{ft}^{3} / \mathrm{s}\right)\end{array}$ \\
\hline 1 & Apri1 1-4, 1970 & 1.85 & 0.50 & 900 & 0.24 & 738 \\
\hline 2 & November $11-14,1970$ & 2.25 & .47 & 802 & .39 & 1,050 \\
\hline 3 & October $10-11,1971$ & $2.201 /$ & .20 & 695 & .31 & 625 \\
\hline 4 & May 30-June 2, 1972 & $1.561 /$ & .14 & 526 & .10 & 611 \\
\hline 5 & June 21-23, 1972 & 4.90 & 1.74 & 7,500 & 1.14 & 5,820 \\
\hline 6 & Ju1y 13-15, 1972 & 1.35 & .19 & 622 & .13 & 389 \\
\hline 7 & November 13-16, 1972 & 2.78 & .66 & 1,360 & .95 & 1,940 \\
\hline 8 & November 21-22, 1972 & 1.30 & .24 & 559 & .18 & 669 \\
\hline 9 & December 8-11, 1972 & 1.50 & .32 & 573 & .32 & 642 \\
\hline 10 & March 31-April 4, 1973 & 1.83 & .46 & 695 & .30 & 759 \\
\hline 11 & May $26-30,1973$ & 2.23 & .41 & 949 & .72 & 1,740 \\
\hline 12 & June 29-30, 1973 & 4.501/ & 1.74 & 7,850 & 1.91 & 7,710 \\
\hline 13 & Apri1 13-15, 1974 & $1.401 /$ & .26 & 678 & .50 & 935 \\
\hline 14 & December $15-17,1974$ & $1.631 /$ & .18 & 551 & .16 & 685 \\
\hline 15 & Apri1 24-27, 1975 & 2.47 & .66 & 874 & .21 & 456 \\
\hline 16 & June $11-15,1975$ & 2.41 & .44 & 901 & .58 & 1,070 \\
\hline 17 & June 27-30, 1975 & 2.64 & .16 & 505 & .33 & 764 \\
\hline 18 & July $13-17,1975$ & 4.55 & 1.47 & 2,320 & 1.41 & 3,670 \\
\hline 19 & October $17-21,1975$ & 2.50 & .41 & 829 & .65 & 1,480 \\
\hline 20 & March 31-April 3, 1976 & $2.031 /$ & .33 & 553 & .44 & 704 \\
\hline 21 & June $1-4,1976$ & 1.71 & .27 & 935 & .10 & 601 \\
\hline 22 & July $11-12,1976$ & 2.73 & .29 & 1,460 & .63 & 1,360 \\
\hline 23 & August 27-28, 1976 & $2.211 /$ & .21 & 804 & .11 & 600 \\
\hline 24 & October 20-22, 1976 & 2.03 & .31 & 839 & .29 & 846 \\
\hline 25 & March 12-15, 1977 & 2.20 & .26 & 690 & .44 & 931 \\
\hline
\end{tabular}

$1 /$ Brandywine Manor rain gage. A11 other data are from the Coatesville rain gage.

2 Peak discharge given for West Branch Brandywine Creek at Coatesville. 
Table 4.--Soil-moisture and infiltration parameter values for the Modena subbasin model

\begin{tabular}{lc}
\hline Parameter & Value used in model \\
\cline { 2 - 2 } PSP & 1.20 \\
KSAT & .06 \\
RGF & 19.63 \\
BMSN & 2.93 \\
EVC & .75 \\
RR & .9 \\
DRN & 1.0 \\
\hline
\end{tabular}


Table 5.--Comparison of observed and simulated runoff volumes and peak discharges for the Modena subbasin model calibration

\begin{tabular}{|c|c|c|c|c|c|c|}
\hline \multirow[b]{2}{*}{$\begin{array}{l}\text { Storm } \\
\text { Number }\end{array}$} & \multirow[b]{2}{*}{ Storm Date } & \multirow{2}{*}{$\begin{array}{l}\text { Rainfall at } \\
\text { Coatesville } \\
\text { (inches) }\end{array}$} & \multicolumn{2}{|c|}{ Observed } & \multicolumn{2}{|c|}{ Simulated } \\
\hline & & & $\begin{array}{l}\begin{array}{l}\text { Runoff volume } \\
\text { (inches) }\end{array} \\
\end{array}$ & $\begin{array}{l}\text { Peak discharge } 1 / \\
\left(\mathrm{ft}^{3} / \mathrm{s}\right)\end{array}$ & $\begin{array}{l}\text { Runoff volume } \\
\text { (inches) }\end{array}$ & $\begin{array}{c}\text { Peak discharge }- \\
\left(\mathrm{ft}^{3} / \mathrm{s}\right)\end{array}$ \\
\hline 1 & March 31-April 5, 1970 & 1.95 & 1.24 & 1,430 & 0.34 & 1,100 \\
\hline 2 & August 27-28, 1971 & 5.00 & 1.15 & 2,410 & 1.21 & 2,350 \\
\hline 3 & September 11-15, 1971 & 5.04 & 1.67 & 904 & 2.20 & 1,970 \\
\hline 4 & June 21-23, 1972 & 4.90 & 4.91 & 7,890 & 1.79 & 7,600 \\
\hline 5 & Ju1y 13-14, 1972 & 1.35 & .17 & 761 & .29 & 760 \\
\hline 6 & November $13-16,1972$ & 2.78 & 1.15 & 2,040 & 1.19 & 2,120 \\
\hline 7 & May $26-31,1973$ & 2.23 & 1.07 & 1,420 & .99 & 2,180 \\
\hline 8 & August $17-18,1974$ & 2.30 & .79 & 1,240 & 1.22 & 2,730 \\
\hline 9 & June $27-30,1975$ & 2.64 & 1.28 & 1,000 & .66 & 1,200 \\
\hline 10 & September 22-27, 1975 & 4.49 & 1.82 & 858 & 1.45 & 1,160 \\
\hline 11 & October 20-22, 1976 & 2.03 & .94 & 1,380 & .57 & 976 \\
\hline 12 & March 22-24, 1977 & 2.00 & .98 & 1,640 & 1.01 & 1,660 \\
\hline 13 & July $3-6,1978$ & 2.56 & .82 & 2,000 & .60 & 1,570 \\
\hline 14 & July 21-22, 1979 & 8.35 & 3.16 & 4,690 & 6.28 & 6,700 \\
\hline
\end{tabular}

I/Peak discharge given for West Branch Brandywine at Modena. 
Table 6.--Comparison of observed and simulated runoff volumes and peak discharges for the Modena subbasin model verification

\begin{tabular}{|c|c|c|c|c|c|c|}
\hline \multirow[b]{2}{*}{$\begin{array}{l}\text { Storm } \\
\text { Number }\end{array}$} & \multirow[b]{2}{*}{$\begin{array}{l}\text { Storm } \\
\text { Dates }\end{array}$} & \multirow{2}{*}{$\begin{array}{l}\text { Rainfall at } \\
\text { Coatesville } \\
\text { (inches) }\end{array}$} & \multicolumn{2}{|c|}{ Observed } & \multicolumn{2}{|c|}{ Simulated } \\
\hline & & & $\begin{array}{l}\begin{array}{c}\text { Runoff volume } \\
\text { (inches) }\end{array} \\
\end{array}$ & $\begin{array}{c}\text { Peak discharge } 1 \text { - } \\
\left(\mathrm{ft}^{3} / \mathrm{s}\right)\end{array}$ & $\begin{array}{l}\text { Runoff volume } \\
\text { (inches) }\end{array}$ & $\begin{array}{c}\text { Peak discharge I/ } \\
\left(\mathrm{ft}^{3} / \mathrm{s}\right)\end{array}$ \\
\hline 1 & June 5-7, 1970 & 1.55 & 0.61 & 1,310 & 0.43 & 879 \\
\hline 2 & Ju1y 31-August 2, 1970 & 2.69 & .57 & 1,700 & 1.14 & 1,660 \\
\hline 3 & August $1-5,1971$ & 2.77 & 1.13 & 889 & .52 & 795 \\
\hline 4 & November 19-21, 1972 & 1.30 & .45 & 721 & .34 & 775 \\
\hline 5 & December 8-10, 1972 & 1.50 & .53 & 762 & .46 & 944 \\
\hline 6 & Apri1 24-28, 1975 & 2.02 & 1.55 & 1,360 & .33 & 1,010 \\
\hline 7 & May 31-June 2, 1975 & 1.22 & 1.08 & 1,190 & .16 & 850 \\
\hline 8 & June 11-14, 1975 & 2.41 & 1.58 & 1,620 & .87 & 1,260 \\
\hline 9 & October $17-21,1975$ & 2.50 & 1.09 & 1,290 & .86 & 1,990 \\
\hline 10 & June $1-3,1976$ & 1.71 & .81 & 1,420 & .20 & 1,040 \\
\hline 11 & July 10-12, 1976 & 2.77 & 1.30 & 2,240 & .94 & 2,230 \\
\hline 12 & Apri1 4-7, 1977 & 2.05 & .51 & 1,520 & .56 & 1,560 \\
\hline 13 & May $13-16,1978$ & 2.72 & .26 & 1,000 & .42 & 1,130 \\
\hline 14 & June $26-29,1978$ & 3.06 & .69 & 3,330 & 1.41 & 3,040 \\
\hline
\end{tabular}

I/Peak discharge given for West Branch Brandywine Creek at Modena. 
Predictive simulations were made for the Coatesville and Modena subbasins with selected storms. The hydrograph of each storm shows the response of streamflow in a subbasin to a particular precipitation event for the current state of development. Predictive simulations with the same precipitation data show the change in streamflow that would result from changes in the subbasin.

The June 29-30, 1973, and July 11-12, 1976, storms in the Coatesville subbasin were selected for predictive simulations. The observed and simulated hydrographs for the June 29-30, 1973, storm, which produced the highest peak discharge of record $\left(8,100 \mathrm{ft}^{3} / \mathrm{s}\right)$, are shown in figure 4 . This peak discharge has a 1.9 percent chance of being exceeded in any 1 year (53-year recurrence interval). The July 11-12, 1976, storm produced a peak discharge $\left(1,480 \mathrm{ft}^{3} / \mathrm{s}\right)$ near the mean annual flood discharge $\left(1,400 \mathrm{ft}^{3} / \mathrm{s}\right)$. The peak discharge of the mean annual flood has a 50 percent chance of being exceeded in any 1 year (2-year recurrence interval). The observed and simulated hydrographs for this storm are shown in figure 5. The June 21-23, 1972, storm was also used in some of the predictive simulations. This storm produced a peak discharge of $7,770 \mathrm{ft} 3 / \mathrm{s}$, having a 2.3 percent chance of being exceeded in any 1 year (43-year recurrence interval).

The June 21-23, 1972, and August 27-28, 1971, storms in the Modena subbasin were selected for predictive simulations. The June 21-23, 1972, storm, Hurricane Agnes, produced the second highest peak discharge $\left(7,940 \mathrm{ft}^{3} / \mathrm{s}\right)$ on record. This discharge has a 3.4 percent chance of being exceeded in any 1 year (29-year recurrence interva1). The observed and simulated hydrographs for this storm are shown in figure 6 . The August 27-28, 1971, storm produced a peak discharge $\left(3,320 \mathrm{ft}^{3} / \mathrm{s}\right)$ near the mean annual flood discharge $\left(2,900 \mathrm{ft}^{3} / \mathrm{s}\right)$. The observed and simulated hydrographs for this storm are shown in figure 7.

\section{Effects of Projected Population Growth}

Subbasin models were based on current population. Projected population figures are for the year 2000 (Chester County Planning Commission, 1980). The impervious area is different for each overland flow segment in the mode1. It is not known how much population will grow in each segment or exactly how much additional impervious area this growth will create.

Therefore, a simple method of increasing the impervious area was used. The projected percentage increase in population was calculated, and the amount of impervious and effective impervious area for each overland flow segment was increased by that percentage. Projected percentages of increase in population are given in table 7. The selected storms in each subbasin were simulated with the new impervious and effective impervious area values. Simulated peak discharges for West Branch Brandywine Creek at Coatesville, West Branch Brandywine Creek at Modena, and Sucker Run at State Route 82 are given in table 8 . Stream stage shown in the predictive simulation tables for the gaging stations are taken from rating curves in effect during September 1980. Stage-discharge relationships are not available at other sites in the subbasins. 


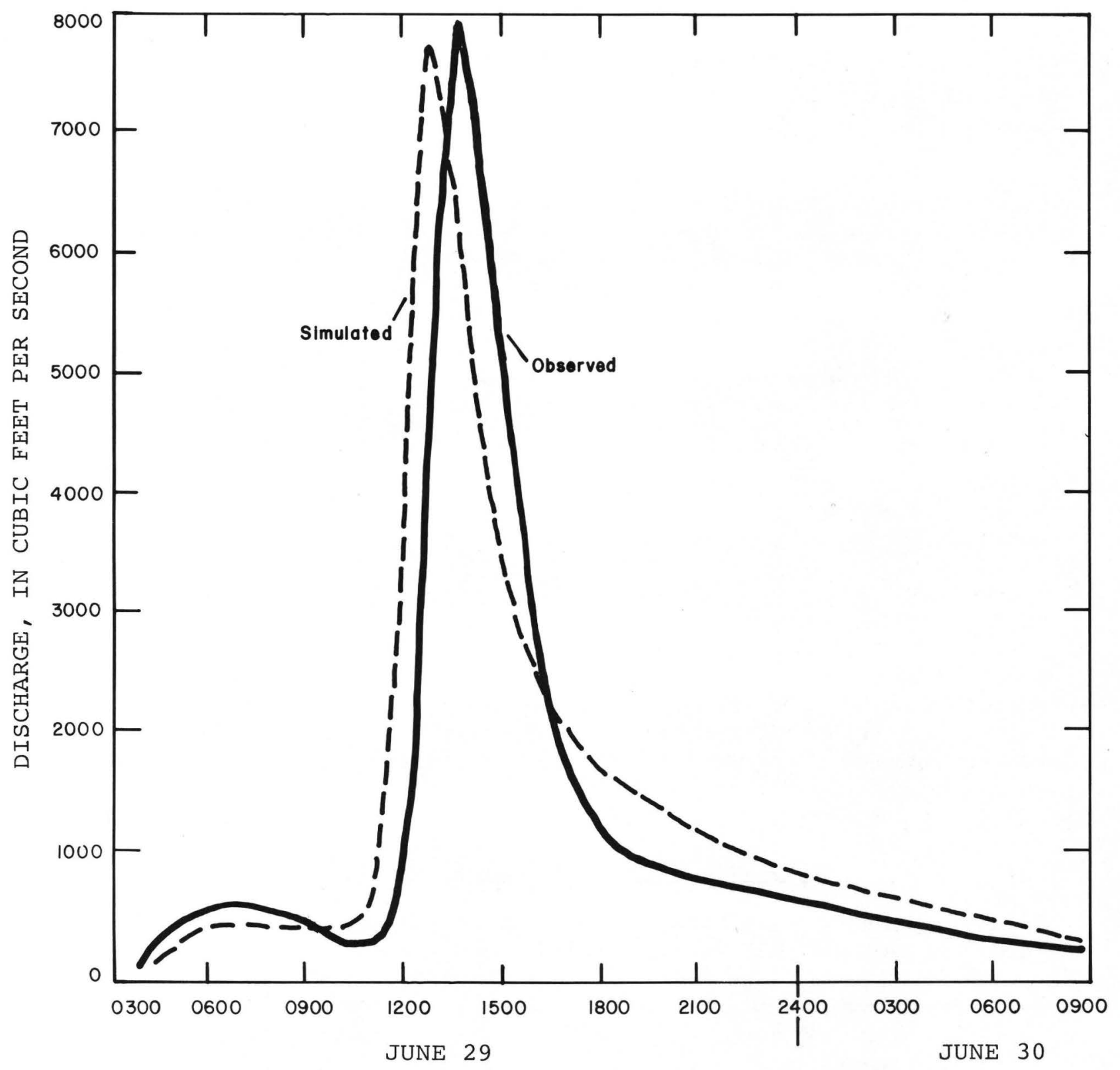

Figure 4.--Observed and simulated hydrographs for the June 29-30, 1973, storm in the Coatesville subbasin. 


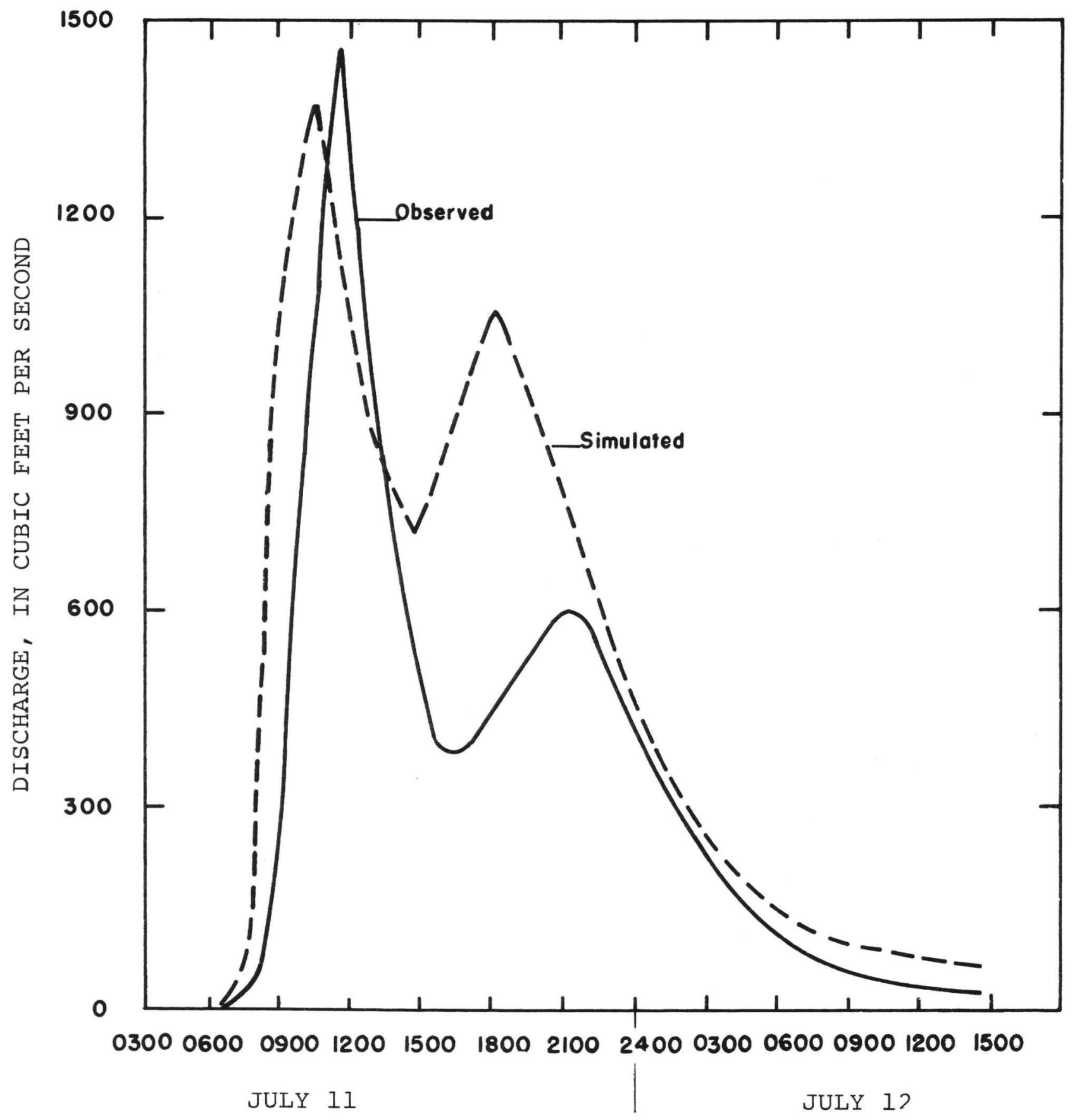

Figure 5.--Observed and simulated hydrographs for the July 11-12, 1976, storm in the Coatesville subbasin. 


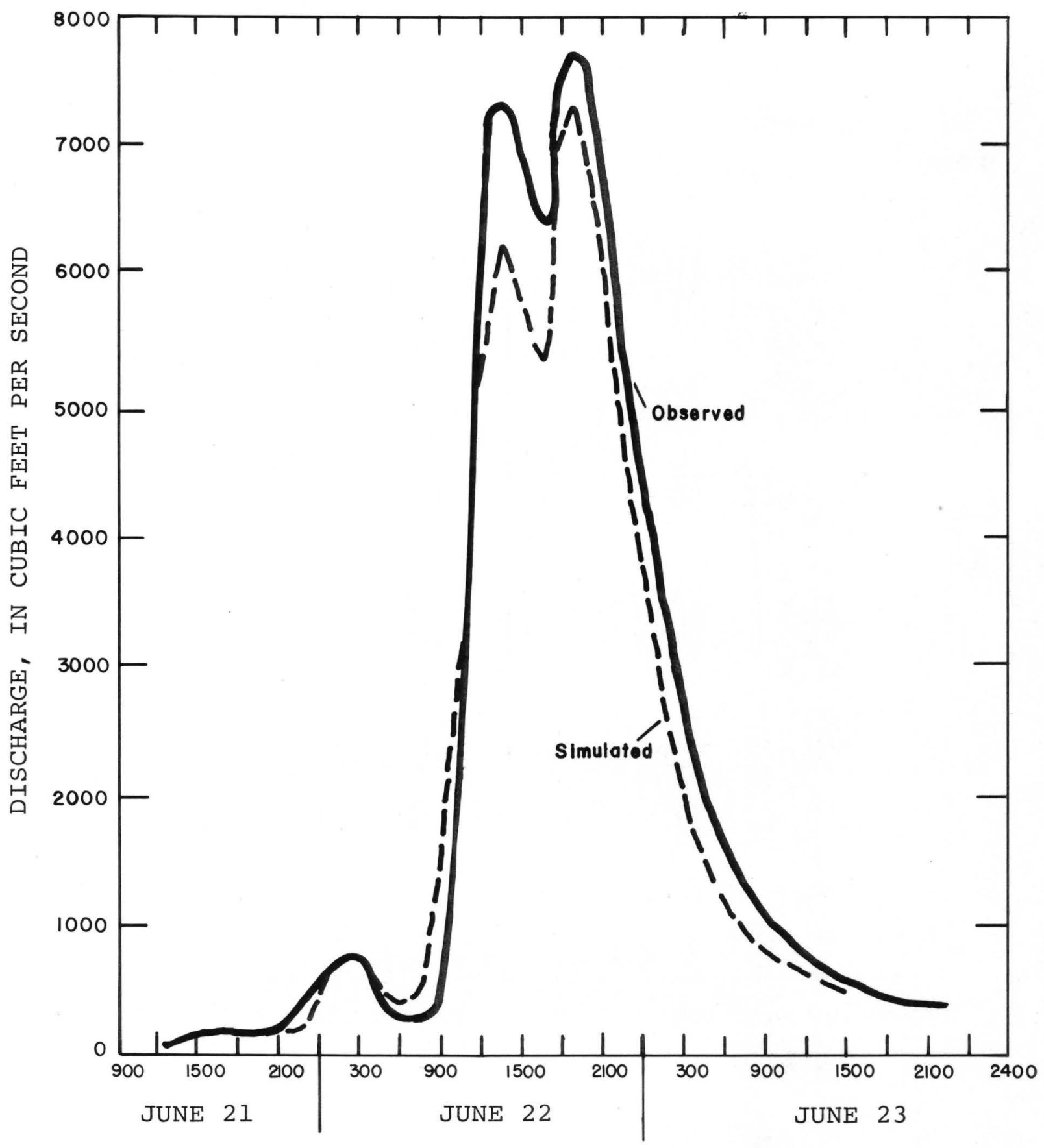

Figure 6.--Observed and simulated hydrographs for the June 21-23, 1972, storm in the Modena subbasin. 


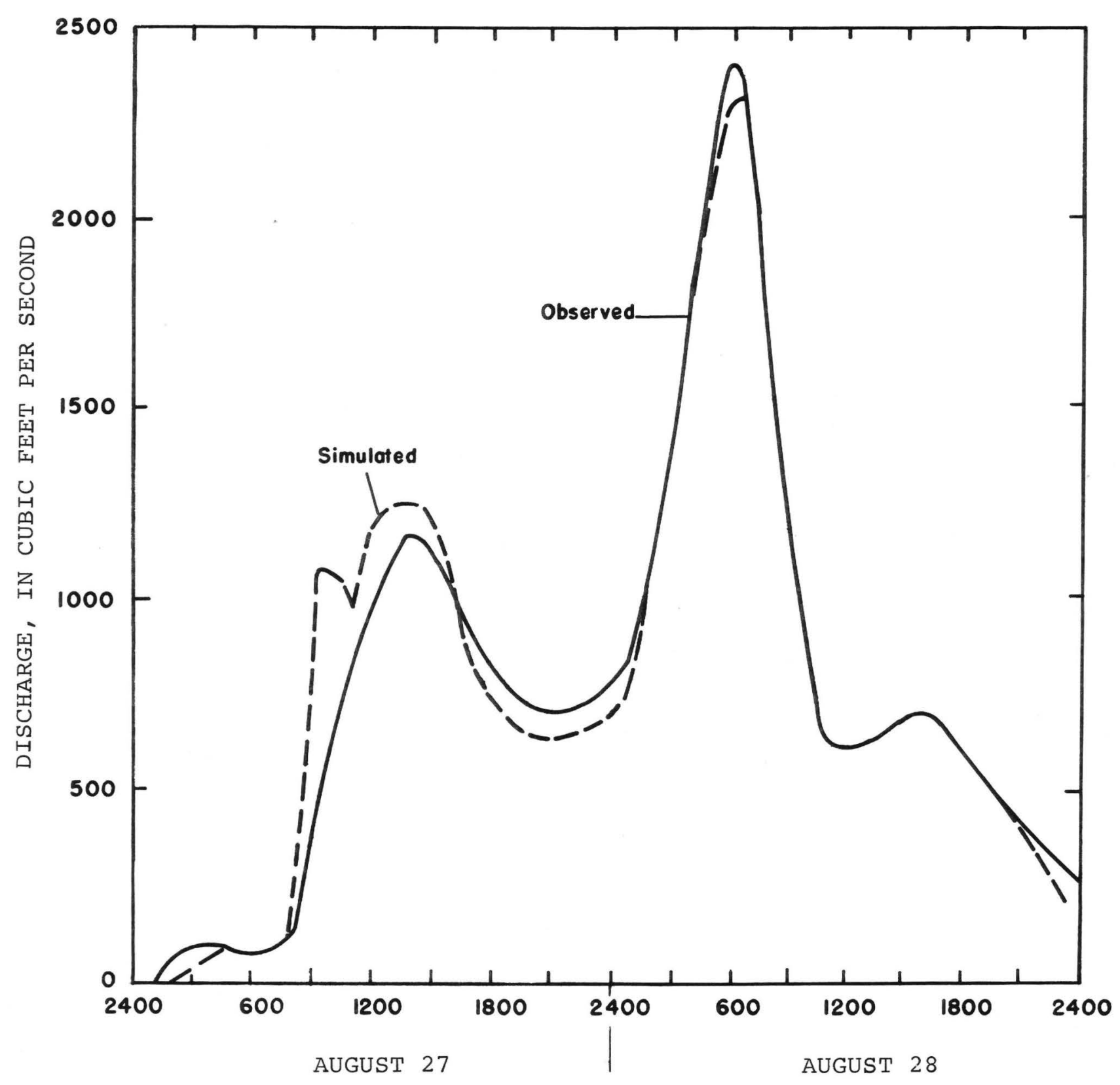

Figure 7.--Observed and simulated hydrographs for the August 27-28, 1971, storm in the Modena subbasin. 
Table 7.--Projected population increases for municipalities in modeled subbasins

\begin{tabular}{lc}
\hline \multicolumn{1}{c}{ Municipality } & $\begin{array}{r}\text { Projected } \\
\text { in population }\end{array}$ \\
Caln Township & 77 \\
Coatesville & 31 \\
East Fallowfield Township & 54 \\
Honeybrook Township & 72 \\
Modena & -13 \\
Sadsbury Township & 45 \\
South Coatesville & 29 \\
West Brandywine Township & 67 \\
West Caln Township & 69 \\
Valley Township & 45 \\
\hline
\end{tabular}


Table 8.--Results of simulations with projected population for selected storms in the Coatesville and Modena subbasins

\begin{tabular}{|c|c|c|c|c|c|c|c|c|}
\hline \multirow[b]{2}{*}{ Storm date } & \multicolumn{3}{|c|}{ Current Population } & \multicolumn{5}{|c|}{ Projected Population } \\
\hline & $\begin{array}{c}\text { Simulated } \\
\text { runoff } \\
\text { (inches) }\end{array}$ & $\begin{array}{c}\text { Simulated } \\
\text { peak } \\
\text { discharge } \\
\left(\mathrm{ft}^{3} / \mathrm{s}\right)\end{array}$ & $\begin{array}{l}\text { Stage } \\
\text { (feet) }\end{array}$ & $\begin{array}{c}\text { Simulated } \\
\text { runoff } \\
\text { (inches) }\end{array}$ & $\begin{array}{c}\text { Increase } \\
\text { in } \\
\text { runoff } \\
\text { (percent) }\end{array}$ & $\begin{array}{c}\text { Simulated } \\
\text { peak } \\
\text { discharge } \\
\left(\mathrm{ft}^{3} / \mathrm{s}\right)\end{array}$ & $\begin{array}{l}\text { Increase } \\
\text { in peak } \\
\text { discharge } \\
\text { (percent) }\end{array}$ & $\begin{array}{l}\text { Stage } \\
\text { (feet) }\end{array}$ \\
\hline
\end{tabular}

WEST BRANCH BRANDYWINE CREEK AT COATESVILLE

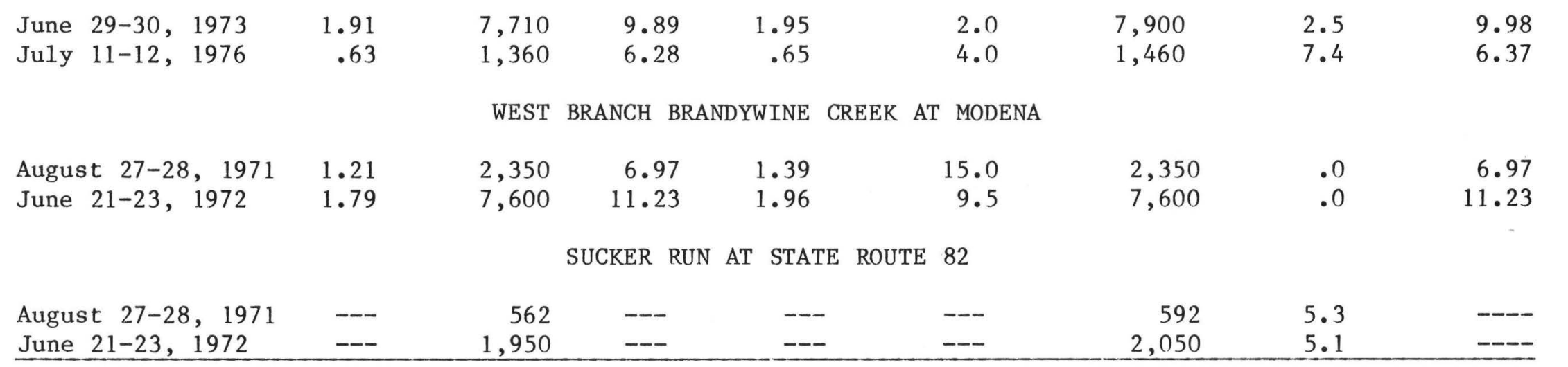


In both subbasins, the simulations with projected population growth show a greater percentage increase in runoff volume for the low-magnitude flood than for the high-magnitude flood. During high-magnitude storms, pervious areas become saturated and tend to act as impervious areas. Additional impervious area does not contribute much more runoff. During low-magnitude storms, the impervious areas contribute most of the runoff; much of the pervious area does not contribute runoff. For low-magnitude storms, additional impervious area tends to increase runoff volume. Runoff volume increased 2 percent and peak discharge increased 2.5 percent at West Branch Brandywine Creek at Coatesville for the high-magnitude storm; runoff increased 4 percent and peak discharge increased 7.4 percent for the lowmagnitude storm. Runoff volume increased 9.5 percent for the highmagnitude storm and 15 percent for the low-magnitude storm at West Branch Brandywine Creek at Modena. The peak discharge did not change.

\section{Effects of Proposed Flood-Control Structures}

A flood-control structure was simulated by adding a reservoir segment with the storage-outflow relationship of the structure to the model. Selected storms were then simulated with the added segment. The effects of four flood-control structures were simulated. Three flood-control structures, PA-436D, WA-2, and PA-430 are to be located in the Coatesville subbasin and one, PA-428, is to be located in the Modena subbasin. Engineering data on these flood-control structures can be found in Bourguard, Geil, and Associates (1958) and Geo-Technical Services (1974).

PA-436D, to be located on West Branch Brandywine Creek between the Honeybrook stream gage and Icedale Lake, is proposed as a multipurpose reservoir having 11,100 acre-feet of flood water storage. It will control the drainage of $18.8 \mathrm{mi}^{2}$.

WA-2 is to be located on Birch Run 0.3 miles upstream from West Branch Brandywine Creek. It is proposed two ways: (1) as a water supply and recreational reservoir; and (2) as a dry dam. A dry dam does not normally have a pool; it will cause flood water to be temporarily impounded by restricting outflow. The dry dam would have a storage capacity of 1,260 acre-feet. The drainage area to be controlled by WA-2 is $4.1 \mathrm{mi}^{2}$.

PA-430 is to be located on Rock Run 0.4 miles upstream from Rock Run reservoir. It is proposed as a dry dam with a storage capacity of 760 acre-feet and will control a drainage area of $4.4 \mathrm{mi}^{2}$.

PA-428 is to be located on Sucker Run, 2.2 miles upstream from West Branch Brandywine Creek. It is proposed as a dry dam with a storage capacity of 249 acre-feet, and will control a drainage area of $1.3 \mathrm{mi}^{2}$.

Flood-control structure data given in this report is summarized in table 9. Locations of the proposed flood-control structures are shown in figure 8 . 


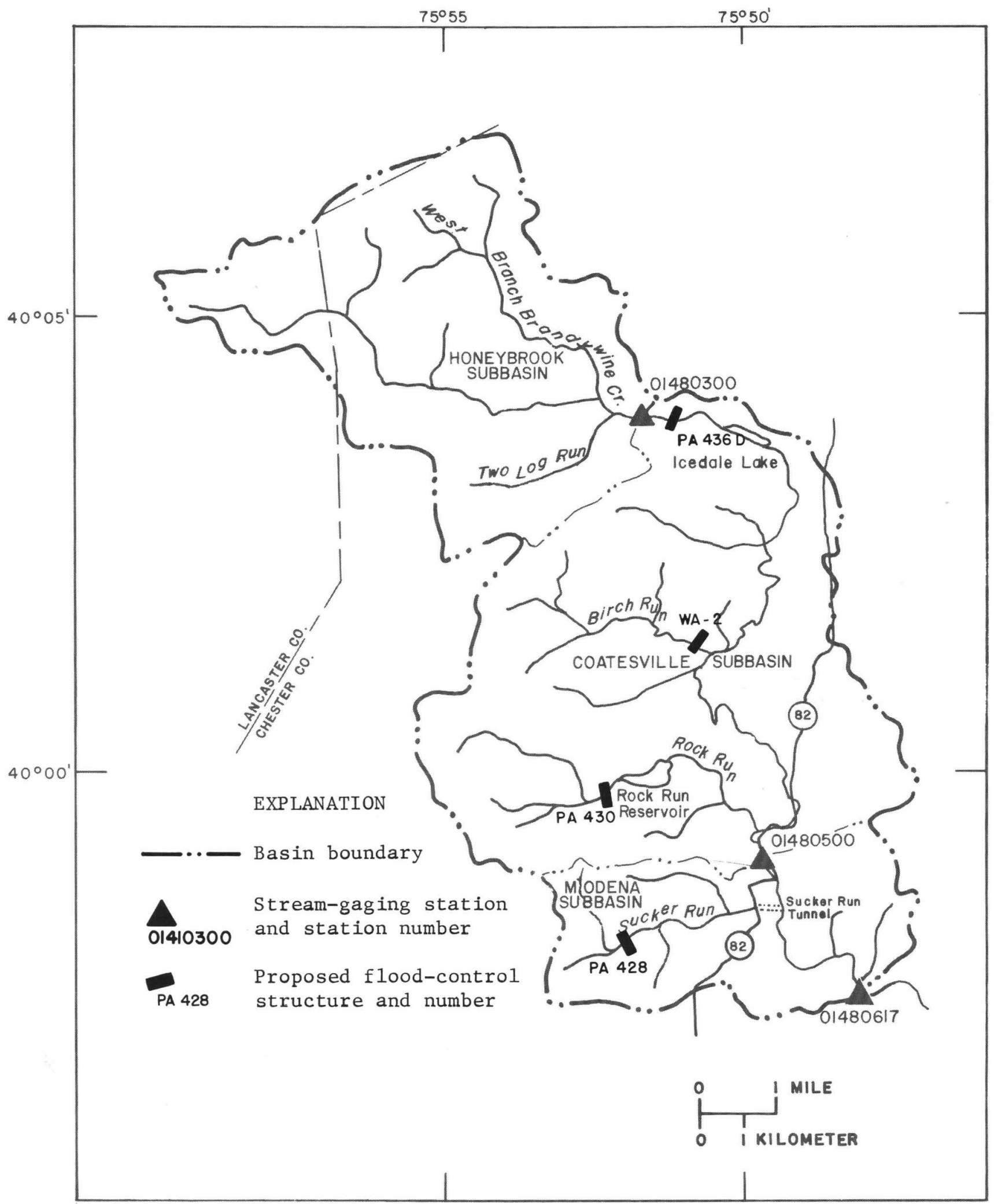

Figure 8.--Location of proposed flood-control structures. 
Table 9.--Summary of proposed flood-control structure data

\begin{tabular}{|c|c|c|c|c|}
\hline $\begin{array}{l}\text { Flood- } \\
\text { control } \\
\text { structure }\end{array}$ & Location & Type & $\begin{array}{l}\text { Storage } \\
\text { capacity } \\
\text { (acre-feet) }\end{array}$ & $\begin{array}{c}\text { Controlled } \\
\text { drainage area } \\
\left(\mathrm{mi}^{2}\right)\end{array}$ \\
\hline$P A-436 D$ & $\begin{array}{l}\text { West Branch } \\
\text { Brandywine Creek }\end{array}$ & $\begin{array}{l}\text { Multi-purpose } \\
\text { reservoir }\end{array}$ & 11,100 & 18.8 \\
\hline WA-2 & Birch Run & $\begin{array}{l}\text { Water supply- } \\
\text { recreational } \\
\text { reservoir }\end{array}$ & 1,002 & 4.1 \\
\hline WA-2 & Birch Run & Dry dam & 1,260 & 4.1 \\
\hline$P A-430$ & Rock Run & Dry dam & 760 & 4.4 \\
\hline$P A-428$ & Sucker Run & Dry dam & 249 & 1.3 \\
\hline
\end{tabular}

\section{Coatesville Subbasin}

Simulations of selected storms with flood-control structures for both current and projected population were made for the Coatesville subbasin. WA-2 reduced the peak discharge by about the same amount whether it was modeled as a dry dam or as a water supply and recreational reservoir. Simulation results are given for WA-2 modeled as a dry dam. Simulation results for West Branch Brandywine Creek at Coatesville are given in table 10 .

In the simulation of the June 21-23, 1972, storm, PA-436D achieved the largest reduction in peak discharge; in the simulation of the June 29-30, 1973, storm, WA-2 achieved the largest reduction in peak discharge.

PA-436D is immediate1y downstream from the Honeybrook subbasin. During the June 21-23, 1972, storm, an observed peak discharge of $8,140 \mathrm{ft}^{3} / \mathrm{s}$ entered the Coatesville subbasin from the Honeybrook subbasin. In this simulation, PA-436D reduced the peak discharge by storing the large inflow from the Honeybrook subbasin. During the June 29-30, 1973, storm, the observed peak discharge entering the Coatesville subbasin from the Honeybrook subbasin was only $776 \mathrm{ft}^{3} / \mathrm{s}$. Most of the discharge observed leaving the Coatesville subbasin from this storm is runoff from the Coatesville subbasin, as there was relatively little inflow from the Honeybrook subbasin. During this storm, PA-436D, controlling inflow from the Honeybrook subbasin, had less effect than WA-2 which controls runoff within the Coatesville subbasin. 
Table 10.--Results of simulations of selected storms with proposed flood-control structures in the Coatesville subbasin

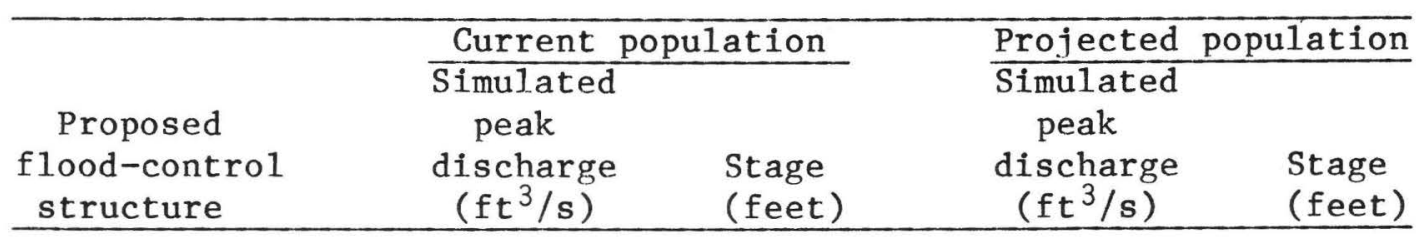

WEST BRANCH BRANDYWINE CREEK AT COATESVILLE

June 21-23, 1972, storm

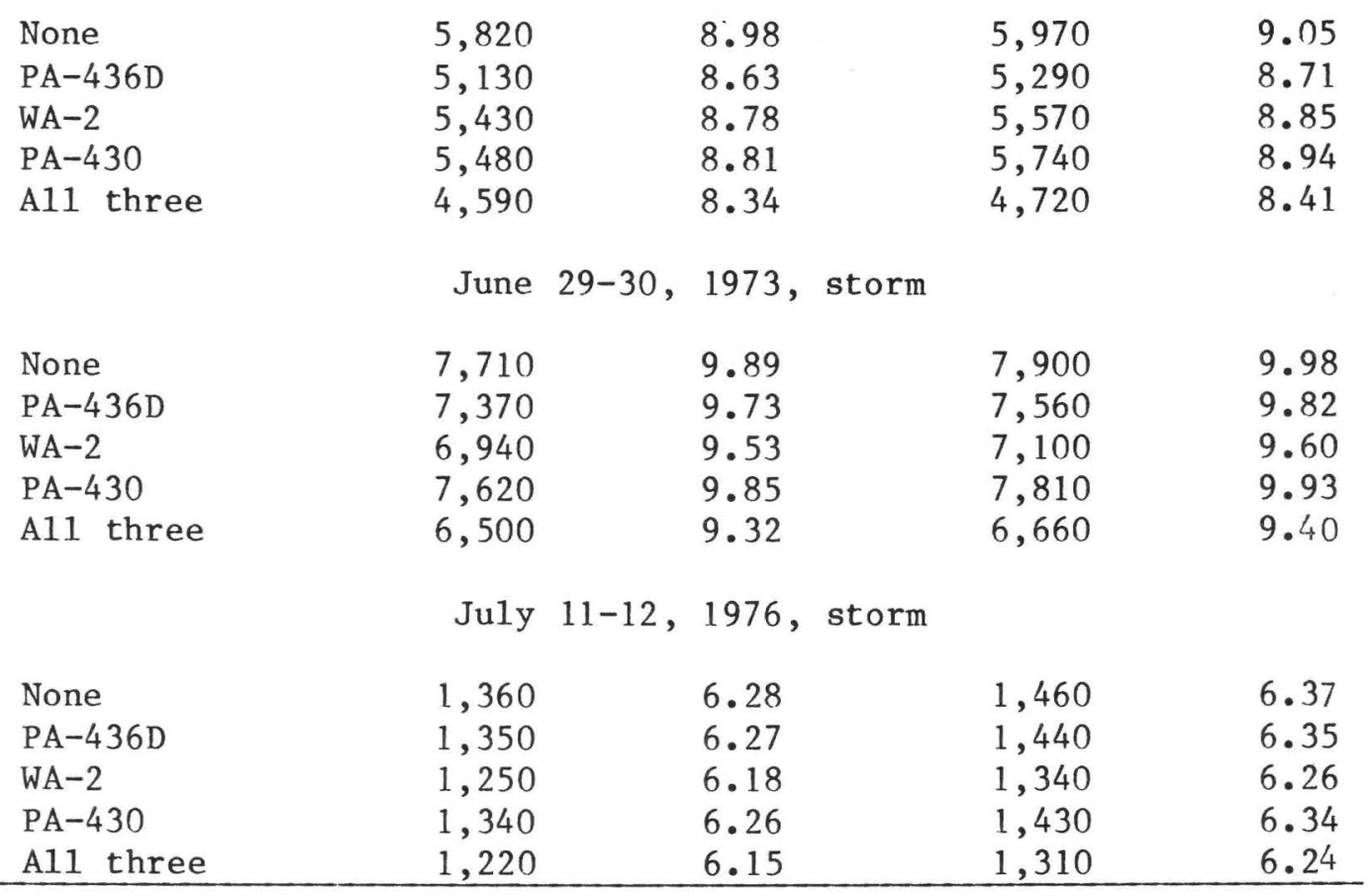


WA-2 and PA-430 contro1 about the same drainage area, but WA-2 causes a greater reduction in peak discharge at Coatesville. PA-430 is to be located upstream from Rock Run Reservoir, which is a water-supply impoundment that provides some flood water storage. PA-430 would, therefore, be located upstream from an existing flood-control structure. Its effect on reducing peak discharge would be less than if there were no flood-control structure downstream from it, as is the case with WA-2. The effectiveness of PA-436D in reducing peak discharge would probably be similarly reduced because of its proposed location upstream from Icedale Lake, which also provides some flood water storage.

The effectiveness of any proposed flood-control structure in the Coatesville subbasin depends upon the rainfall pattern in the West Branch Brandywine Creek basin and whether or not it will be located upstream from an existing flood-control structure.

To determine the effects of flood-control structures in the Coatesville subbasin on a flood having a 1 percent chance of being exceeded in any 1 year (100-year recurrence interval), a hypothetical storm was created by increasing the rainfall for the June 21-23, 1972, storm. A 1 percent chance flood at the Ccatesville gage, calculated from Flippo (1977), would have a peak discharge of $9,500 \mathrm{ft}^{3} / \mathrm{s}$. The hypothetical storm produced a simulated peak discharge of $9,630 \mathrm{ft}^{3} / \mathrm{s}$. The results of simulations with this hypothetical storm with and without the proposed flood-control structures for projected population growth in the Coatesville subbasin are given in table 11. The simulation with all three proposed flood-control structures indicate the peak discharge will be reduced to the magnitude of a flood that has a 2 percent chance of being exceeded in any 1 year (50-year recurrence interval).

Table 11.--Results of simulations of a hypothetical 1 percent chance flood with proposed flood-control structures in the Coatesville subbasin

\begin{tabular}{lcc}
\hline & Simulated & \\
Proposed flood- & peak discharge & Stage \\
control structure & $\left(\mathrm{ft}^{3} / \mathrm{s}\right)$ & (feet) \\
\hline
\end{tabular}

WEST BRANCH BRANDYWINE CREEK AT COATESVILLE

\begin{tabular}{llr} 
None & 9,630 & 10.75 \\
PA-436D & 8,840 & 10.40 \\
WA-2 & 8,940 & 10.45 \\
PA-430 & 9,550 & 10.72 \\
A11 three & 7,920 & 9.99 \\
\hline
\end{tabular}


Simulations of three selected storms were made with PA-428 in the Modena subbasin with both current and projected population. Because data were not available from the Coatesville rain gage, the June 29-30, 1973, storm was simulated with unit data from the Brandywine Manor rain gage. The model simulated a peak discharge of $9,330 \mathrm{ft} / \mathrm{s}$ at station 01480617 , which compares well with the observed peak discharge of $9,600 \mathrm{ft} / \mathrm{s}$ for this storm. A 1 percent chance flood (100-year recurrence interval) would produce a peak discharge of $3,790 \mathrm{ft}^{3} / \mathrm{s}$ on Sucker Run at State Route 82 (calculated from Flippo, 1977). The simulation of the June 29-30, 1973, storm produced a peak discharge of $3,940 \mathrm{ft}^{3} / \mathrm{s}$ on Sucker Run at State Route 82 . Simulation results with and without PA-428 for West Branch Brandywine Creek at Modena and Sucker Run at State Route 82 are given in table 12 .

The simulation of the June 21-23, 1972, storm shows that PA-428 increased the peak discharge at Modena; the simulation of the June 29-30, 1973, storm shows PA-428 had no effect on peak discharge at Modena. During the June 21-23, 1972, storm, PA-428 lowered the peak discharge of Sucker Run, but the slow release of stored water from PA-428 maintained a higher flow in Sucker Run after the peak. This higher flow from Sucker Run combined with the flow of West Branch Brandywine Creek to raise the peak discharge at Modena, which occured almost 10 hours after the peak discharge of Sucker Run. At State Route 82, Sucker Run flows through an 1,800 foot tunnel before discharging into West Branch Brandywine Creek (fig. 8). The tunnel capacity of $1,050 \mathrm{ft}^{3} / \mathrm{s}$ limits the flow contributed by Sucker Run. At the time of the peak discharge at Modena during the June 21-23, 1972, storm, the flow of Sucker Run was less than the capacity of the tunnel. However, during the storm of June 29-30, 1973, the peak discharge at Modena occurred about 2 hours after the peak discharge of Sucker Run. The capacity of the tunnel under State Route 82 was exceeded during this period with or without PA-428, so the peak discharge at Modena was the same.

To determine the effects of flood-control structures in the Coatesville subbasin on peak discharge at Modena, the storms of June 21-23, 1972, and July 29-30, 1973, were first simulated with flood-control structures in the Coatesville subbasin. Unit discharge from these storms at West Branch Brandywine Creek at Coatesville were used as the input hydrograph to the Modena subbasin. The storms were then simulated in the Modena subbasin. Simulation results for West Branch Brandywine Creek at Modena for projected population growth and with PA-428 in the Modena subbasin are given in table 13 . 
Table 12.--Results of simulations of selected storms with proposed flood-control structure PA-428 in the Modena subbasin

\begin{tabular}{lcccc} 
& Current population & & Proiected population \\
\cline { 2 - 6 } & $\begin{array}{c}\text { Simulated } \\
\text { peak }\end{array}$ & & $\begin{array}{c}\text { Simulated } \\
\text { peak }\end{array}$ & \\
Proposed flood- & discharge & Stage & discharge & Stage \\
control structure & $\left(\mathrm{ft}^{3} / \mathrm{s}\right)$ & $(\mathrm{feet})$ & $\left(\mathrm{ft}^{3} / \mathrm{s}\right)$ & (feet) \\
\hline
\end{tabular}

WEST BRANCH BRANDYWINE CREEK AT MODENA

August 27-28, 1971, storm

None

PA-428

$\mathrm{PA}-428$

None

PA-428
2,350

2,370

June 21-23,

7,600

7,690
6.97

6.99

1972, storm

11.23

11.29

June 29-30,

9,330

9,330

12.33

12.33

1973, storm
2,350

2,380

6.97

7.00

SUCKER RUN AT STATE ROUTE 82

7,600

11.23

7,690

11.29

August 27-28, 1971, storm

None

PA-428
562

462
656

536

12.34

12.34

June 21-23, 1972, storm

None
PA-428

None
PA-428

None

PA-428
1,950

1,470

$--$

June 29-30, 1973, storm

$$
3,940
$$

2,880
$--$

1,540

$-$ 
Table 13.--Results of simulations using proiected population for selected storms in the Modena subbasin with flood-control structures located in the Coatesville subbasin

\begin{tabular}{lcc}
\hline & $\begin{array}{c}\text { Simulated peak } \\
\text { discharge } \\
\left(\mathrm{ft}^{3} / \mathrm{s}\right)\end{array}$ & $\begin{array}{c}\text { Stage } \\
\text { (feet) }\end{array}$ \\
\hline
\end{tabular}

WEST BRANCH BRANDYWINE CREEK AT MODENA

June 21-23, 1972, storm

$\begin{array}{lll}\text { None } & 7,690 & 11.29 \\ \text { PA-436D } & 6,810 & 10.71 \\ \text { WA-2 } & 7,230 & 10.99 \\ \text { PA-430 } & 7,170 & 10.95 \\ \text { A11 three } & 6,300 & 10.36\end{array}$

June 29-30, 1973, storm

\begin{tabular}{lll} 
None & 9,340 & 12.34 \\
PA-436D & 9,330 & 12.33 \\
WA-2 & 8,960 & 12.10 \\
PA-430 & 9,640 & 12.52 \\
A11 three & 8,480 & 11.80 \\
\hline
\end{tabular}

PA-436D reduced peak discharge at Modena more than WA-2 in the simulation of the June 21-23, 1972, storm; WA-2 reduced peak discharge at Modena more than PA-436D in the simulation of the June 29-30, 1973, storm. The reasons are given in the discussion of table 10 .

During the June $29-30,1973$, storm, the simulation with PA-430 shows a higher peak discharge at Modena than without any flood-control structures. This happens because PA-430 changes the time of the peak discharge at West Branch Brandywine Creek at Coatesville. In the simulation without flood control, the peak discharge on June 29 occurred at Coatesville at $1 \mathrm{p} . \mathrm{m}$. and at Modena at $1: 15 \mathrm{p} . \mathrm{m}$. In the simulation with PA-430, the peak discharge at Coatesville occured at $1: 45 \mathrm{p} . \mathrm{m}$. and at Modena at 2:15 p.m. This change in the time of the peak discharge at Coatesville resulted in a higher peak discharge at Modena.

\section{SUMMARY}

Three subbasins in the West Branch Brandywine Creek watershed were modeled by the Dawdy, Shaake, and Alley (1978) distributed routing rainfall-runoff model. The Honeybrook subbasin could not be calibrated because the only rainfall data available were from outside the subbasin and produced unsatisfactory results. The Coatesville subbasin was calibrated, but not verified. The Modena subbasin was calibrated and verified. 
Rainfal1-runoff modeling with available data is feasible if a recording rain gage is located in the basin or subbasin being modeled. The Modena subbasin model simulated peak discharges with an average standard error of estimate of 38 percent for the calibration set of storms and 24 percent for the verification set. Some degree of success can be expected when modeling a basin or subbasin if a rain gage is very close to it. The Coatesville subbasin had a rain gage located nearby, but not in the subbasin. The Coatesville subbasin model simulated peak discharges with an average standard error of estimate of 61 percent for the calibration set of storms and 63 percent for the verification set. As these errors were unacceptable, 25 storms from both sets were combined to form a calibration set of storms that produced an error of 34 percent for peak discharge.

Predictive simulations were made with selected storms to determine the effects of projected population and proposed flood-control structures in the Coatesville and Modena subbasins. Peak discharges were simulated for West Branch Brandywine Creek at Coatesville, West Branch Brandywine Creek at Modena, and Sucker Run at State Route 82.

Simulations of projected population growth in both the Coatesville and Modena subbasins showed that runoff volumes would have a greater percentage increase for low-magnitude events than for high-magnitude events. Runoff volume increased 2 percent and peak discharge increased 2.5 percent at West Branch Brandywine Creek at Coatesville for a high-magnitude storm; runoff increased 4 percent and peak discharge increased 7.4 percent for a lowmagnitude storm. Runoff volume increased 9.5 percent for a high-magnitude storm, and increased 15 percent for a low-magnitude storm at West Branch Brandywine Creek at Modena. Peak discharge at Modena did not change.

The effects of three proposed flood-control structures, PA-436D, WA-2, and PA-430, on peak discharge at West Branch Brandywine Creek at Coatesville were simulated. PA-436D had the greatest reduction in peak discharge at Coatesville when a large quantity of runoff entered the Coatesville subbasin from upstream. WA-2 had the greatest reduction in peak discharge when most of the runoff came from within the Coatesville subbasin. Although WA-2 and PA-430 control about the same drainage area, WA-2 reduces the peak discharge at Coatesville more than PA-430 does because PA-430 is to be located upstream from Rock Run Reservoir, which provides some flood water storage.

In the Modena subbasin, the simulated effects of proposed flood-control structure PA-428 showed that it would lower the peak discharge of Sucker Run at State Route 82, and either raise or have no effect on peak discharge at West Branch Brandywine Creek at Modena. The simulations of proposed flood-control structures in the Coatesville subbasin on peak discharge at Modena showed a reduction in peak discharge except for the simulation of the June 29-30, 1973, storm, in which PA-430 raised the peak discharge at Modena by changing the time of the peak discharge at Coatesville. 
Alley, W. M., Dawdy, D. R., and Schaake, J. C., Jr., 1980, Parametricdeterministic urban watershed model: American Society of Civil Engineers, Journal of Hydraulics Division, V. 106, No. HY5, p. 679-690.

Alley, W. M., and Veenhuis, J. E., 1979, Determination of basin characteristics for an urban distributed routing rainfa11-runoff mode1, in Stormwater Management Mode1 Users Group Meeting, May 24-25, 1979, Proceedings: U.S. Environmental Protection Agency, EPA 600/9-79-026, p. 1-27.

Bourguard, Geil, and Associates, 1958, Report on water resources study of Brandywine Creek basin in Pennsylvania: Pennsylvania Department of Forests and Waters, Harrisburg, Pennsylvania.

Carrigan, P. H., Jr., 1973, Calibration of U.S. Geological Survey rainfa11/runoff model for peak flow synthesis--natural basins: U.S. Geological Survey Computer Contribution, 109 p.; available only from U.S. Department of Commerce, National Technical Information Service, Springfield, Virginia 22151 as report PB-226 217.

Chester County Commissioners and Others, 1962, Watershed Work PlanBrandywine Creek Watershed, 71 p.

Chester County Planning Commission, 1963, Natural environment and planning: West Chester, Pennsylvania, $70 \mathrm{p}$.

----1980, Population projections 1980 to 2000: Chester County Planning Commission Bulletin No. 4, 25 p.

Dawdy, D. R., Lichty, R. W., and Bergmann, T. M., 1972, A rainfal1-runoff simulation model for estimation of flood peaks for small drainage basins: U.S. Geological Survey Professional Paper 506-B, 28 p.

Dawdy, D. R., Schaake, J. C., Jr., and Alley, W. M., 1978, Users guide for distributed routing rainfal1-runoff model: U.S. Geological Survey Water-Resources Investigations 78-90, 146 p.

F1ippo, H. N., Jr., 1977, Floods in Pennsylvania: Pennsylvania Department of Environmental Resources Bulletin 13, 59 p.

Geo-Technical Services, 1974, Water resources of Chester County, West Branch of Brandywine Creek--An evaluation of alternative reservoir sites to the Icedale Reservoir (PA436): Harrisburg, Pennsylvania, 28 p.

Green, W. H., and Ampt, G. A., 1911, Studies on soil physics; I, F1ow of air and water through soils: Jour. Agr. Research, v. 4, p. 1-24.

Kunkle, M. W., 1963, Soil survey of Chester and Delaware Counties, Pennsylvania: Soil Conservation Service, Series 1959, No. 19, 124 p. 
Riggs, H. C., 1968, Some statistical tools in hydrology: U.S. Geological Survey Techniques of Water-Resources Investigations, Book 4, Chapter Al, 39 p.

Rosenbrock, H. H., 1960, An automatic method of finding the greatest or least value of a function: Computer Journal, v. 3, p. 175-184.

Soil Conservation Service, 1972, National Engineering Handbook, Sec. 4, Hydrology, Chapter 17, Flood routing: Department of Agriculture, p. 17-1 to $17-93$. 
